\title{
New genus of Psychodinae (Diptera, Psychodidae) from Argentina
}

\author{
Guillermo Omad', Carolina Mangudo² \\ \& Raquel M. Gleiser ${ }^{3}$
}

\begin{abstract}
1. Centro de Investigación Esquel de Montaña y Estepa Patagónicas (CIEMEP), Consejo Nacional de Investigaciones Científicas y Técnicas (CONICET), Universidad Nacional de la Patagonia San Juan Bosco, Sede Esquel. Roca 780, Esquel, Argentina. (guillermoomad178@hotmail.com)

2. INENCO. Universidad Nacional de Salta, Av. Bolivia 5150, A4400FVY. Salta, Argentina. IIET. Instituto de Investigación en Enfermedades Tropicales,

Universidad Nacional de Salta.

3. Centro de Relevamiento y Evaluación de Recursos Agrícolas y Naturales, IMBIV- CONICET. Av. Valparaíso s/n, Córdoba, Argentina and Cátedra de Ecología,

Facultad de Ciencias Exactas, Físicas y Naturales, Universidad Nacional de Córdoba, Córdoba, Argentina.
\end{abstract}

\begin{abstract}
Adults (male and female) and pupae of Chuspilepia saltenia gen. nov., sp. nov. were collected in tree holes in the Yungas rainforest, near San Ramón de la Nueva Orán city, Salta province, Argentina. It was not possible to place this new species in any known genera using the available keys and published descriptions, thus a new genus is proposed for the Neotropical region of Argentina.
\end{abstract}

KEYWORDS. South America, new species, Chuspilepia, rainforest, Neotropical.

RESUMEN. Nuevo género de Psychodinae (Diptera, Psychodidae) de Argentina. Adultos (macho y hembra) y pupa de Chuspilepia saltenia gen. nov., sp. nov. fueron colectados en huecos de árboles en las Yungas cerca de la ciudad de San Ramón de la Nueva Orán, provincia de Salta. No fue posible ubicar esta nueva especie en alguno de los géneros conocidos usando las claves y descripciones disponibles, por ello un nuevo género es propuesto para la región Neotropical de Argentina.

PALABRAS CLAVE. América del Sur, nueva especie, Chuspilepia, bosque lluvioso, Neotropical.

The non Phlebotominae Psychodidae have been highly successful and diverse in South America, with hundreds of species described so far (AlEXander et al., 2001). Phlebotominae, by virtue of its public health importance, has received proper care, and more than 520 species have been described for the Neotropical region (ANDRADE \& GuRGEL-GonÇALVES, 2015). In contrast, the state of knowledge of non-Phlebotomine Psychodidae, although it has increased in recent years, it is still relatively poor, and many taxonomic novelties remain to be described (QuATE \& BRown, 2004).

Psychodinae is with Phlebotominae, the most widely distributed and diverse subfamilies within Psychodidae (Quate \& Brown, 2004). Such as Phlebotominae, Psychodinae it is currently composed of more than 30 genera and 500 species only in the Neotropical region (WaGner \& IBÁÑEZ-BernaL, 2009). Comparing these data with the relatively low number of described species for Argentina (30) (OMAD, 2012, 2014; OMAD \& Rossi, 2012), it is evident that the group is much more diverse than is known in the country, especially in Neotropical region. To date only eight species are known for the Argentinean Neotropics: Nemopalpus pallipes Shannon \& del Ponte, 1927, Maruina pilosella Quate \& Wirth, 1951, Maruina pebeta Ibáñez-Bernal, 1994, Bruchomyia argentina Quate \& Alexander, 2000, Alepia truncata Bravo et al., 2004 (in OMAD, 2012), Alepia copelata Quate, 1999 (in OMAD \& Rossi, 2012) and Alepia claritae Omad \& Rossi, 2012. In this paper a new genus is described based on adults of both sexes and pupae.

\section{MATERIAL AND METHODS}

Specimens were collected during field sampling carried out from January to April 2011 and 2012, as part of a larger study on mosquito (Diptera: Culicidae) larval habitats. The study was performed in northwest Argentina in the city of San Ramón de la Nueva Orán $\left(23^{\circ} 08^{\prime} \mathrm{S}\right.$, $64^{\circ} 20^{\prime} \mathrm{W}$, elevation 337 m.a.s.l.) and adjacent forested areas. Samples were collected from tree holes using a siphon bottle, following the procedure described by MÜLLER \& MARCONDES (2006) and MANGUDO et al., (2010). Adults were mounted in slides using $10 \%$ potassium hydroxide to clear specimens and Canada balsam as a mounting medium. Drawings were prepared with a drawing mirror on a Leica MZ6 at 40x magnification. Photographs were taken using a Leica DM 500 microscope equipped with a Leica EC3 camera. The morphological terminology follows that of McAlpine (1981) and the specific Psychodidae terminology follows WaGner \& IBáÑEZ-BERnaL (2009). The chaetotaxy of the pupae follows VAILLANT (1971) and Bravo et al., (2014). Holotype and three paratypes (two males and one female) were deposited in the collection of Museo de Ciencias Naturales de la Plata, La Plata, Argentina (MLP). Other specimens were deposited at the collection of CIEMEP, (Centro de Investigación Esquel de Montaña y Estepa Patagónicas, Universidad Nacional de la Patagonia San Juan Bosco, CONICET). 


\section{RESULTS}

\section{Chuspilepia Omad, Mangudo \& Gleiser gen. nov.}

Type species. Chuspilepia saltenia sp. nov. by present designation.

Etymology. The prefix "Chuspi" means fly in quechua, the language of the original inhabitants of the area, "lepia" comes from genus Alepia Enderlein given similarities observed with that genus at first. The name of genus is feminine.

Diagnosis. Palpomere 1 very short, $1 / 3$ of the size of palpomere 2; wings membrane infuscated; last three flagellomeres not reduced, flagellomere 13 nearly square, different than others. Radial fork very close to $R_{4}, R_{2+3}$ very short. Aedeagus complex asymmetrical, gonocoxites fused to gonostylus; cercus globular at base with strong spiniform setae over its surface; cercus without apical tenacula but with two long curved setae.

As this is a new genus, so far monotypic, the diagnosis is tentative, currently it is not possible to separate generic from specific characters so far in this new genus.

\section{Chuspilepia saltenia Omad, Mangudo \& Gleiser sp. nov.}

(Figs 1-17)

Type material. ARGENTINA, Salta province: San Ramón de la Nueva Orán (2311'38.11”S, 64¹8'5.54”W). Holotype $\widehat{\partial}$, 14.I.2012. C. Mangudo col. (MLP). Sample was collected from a tree hole (undetermined species) as a larva using a siphon bottle and reared in laboratory. The tree was located in the Yungas forest, $0.5 \mathrm{~km}$ away from the urban border, at a site connected to downtown by a rural path, through which local people go into the wood mainly for wood extraction. Salta province: San Ramón de la Nueva Orán $\left(23^{\circ} 7.153^{\prime} \mathrm{S}, 64^{\circ} 18.363^{\prime} \mathrm{W}\right)$. Paratype J, 29.II.2012, C. Mangudo col. (MLP). Salta province:

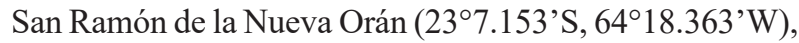
paratypes $\hat{\delta}$ and $\odot$, 14.I.2012, C. Mangudo col. (MLP).

Other specimens studied: ARGENTINA, Salta province: San Ramón de la Nueva Orán $\left(23^{\circ} 7.153^{\prime} \mathrm{S}\right.$, $\left.64^{\circ} 18.363^{\prime} \mathrm{W}\right), 2 \delta^{\top}$ and 9, 14.I.2012, C. Mangudo col. (CIE).

Etymology: the epithet refers to province which the material is from.

Holotype male. (Figs 1-7). Head (Fig. 1) 1.3 times longer than wide; vertex region small, with a broad seta alveoli patch extending uniformly over the entirely area, even reaching the edge of the eye bridge. Eye bridge with three rows of facets, separated by a distance equal to one facet diameters; broad patch of setae alveoli on front, square, uniform, slightly separated in midline by a band without alveoli (Fig. 1), clypeal region broad, with a single patch of uniformly distributed alveoli. Labella bulbous; mouth parts short, 0.3 times the head length. Scape (Fig.
2) 0.2 times longer than wide and 0.2 times longer than pedicel. Antenna short, 0.5 times length of the wing and 2 times longer than palp, with 14 nodiforms and slightly asymmetric flagellomeres (Fig. 3); last flagellomeres not reduced; without visible ascoids but probably these are confused with the setae and are not visible in the optical microscope (Fig. 3). Palp short (Fig. 4), 0.5 times length of the antenna, palpomere 1 very short; palpal formula: 1.0: $3.0: 3.2: 4.5$.

Thorax with two small clusters of setae in region of pteropleura. Wing (Fig. 5) two times longer than wide, second costal node present; Sc short; Radial fork very close to the base of $R_{4}$, which apparently looks that $R_{2+3}$ is absent; medial fork basal; $R_{5}$ ending in wing apex, with a little spurs in base, also with small dark spots on each side of $A_{1}$ and all the veins tips (Fig. 5).

Genitalia. Aedeagal apodeme wide, 0.8 times as wide as long (Fig. 6). Anterior gonocoxal apodemes expanded, but oval shaped and small; genitalia and aedeagal complex asymmetric (Fig. 6). Gonocoxites dimorphic. In dorsal view, right gonocoxite short, wide at the base and tapering to gonostylus; left gonocoxite nearly square, with posterior margin straight and with a conical area with microtrichia on its distal part (Fig. 6). Gonostylus two times the length of gonocoxite, thin, slightly curved near apex, with a little subapical spine and two or three small apical spines (Fig. 6). Aedeagus two times longer than gonostylus, broad at base, tapering to tip, ending in a rounded tip (Fig. 6). Epandrium square, epiproct slightly visible in dorsal view, dome shaped in lateral view. $\mathrm{H}$ ypoproct small, tongue shaped. Cercus rounded at base, with strong spiniform setae over its surface (Fig. 7); tapering towards apex, outer margin smooth, inner margin with a group of short, thick spines. Without apical tenacula but with a short, fine, translucent and slightly curved setae (Fig. 7).

Measurements (in mm): Head high: 0.37, width: 0.54 ; mouthparts length (from clypeus inferior border to apex of labellum): 0.10 ; palpus length: 0.54 ; antenna length: 1.30; wing length: 2.0 , width: 0.80 ; epandrium length: 0.15 ; surstylus length: 0.23 ; gonostylus length: right gonostyli: 0.15 , left gonostyli: 0.12 ; gonocoxite length: 0.07 ; aedeagus length: 0.30; aedeagal apodeme length: 0.14 .

Female. (Figs 8-12). Similar to male except for the following characteristics. Head (Fig. 8) oval in frontal view, 1.3 times wider than long. Eyes bridge with three facet rows, separated by 1 to 1.5 facet diameters (Fig. 8). Scape (Fig. 9) 2.3 times longer than wide, pedicel oval (Fig. 9). Palp (Fig. 10) with palpomere 1 very short; palpal formula: $1.0: 3.2: 3.0: 4.0$.

Thorax. Wing (Fig. 11) quite similar to male as is show in the figure.

Genitalia (Fig. 12). Subgenital plate nearly triangular but with truncate apex, with spiniform setae and micropubescence over its surface (Fig. 12). Genital ducts rounded, longitudinal struts well developed, lateral struts absent. Internal sclerotization on midline, clave shaped, with two parallel bars on sides; genital ducts 

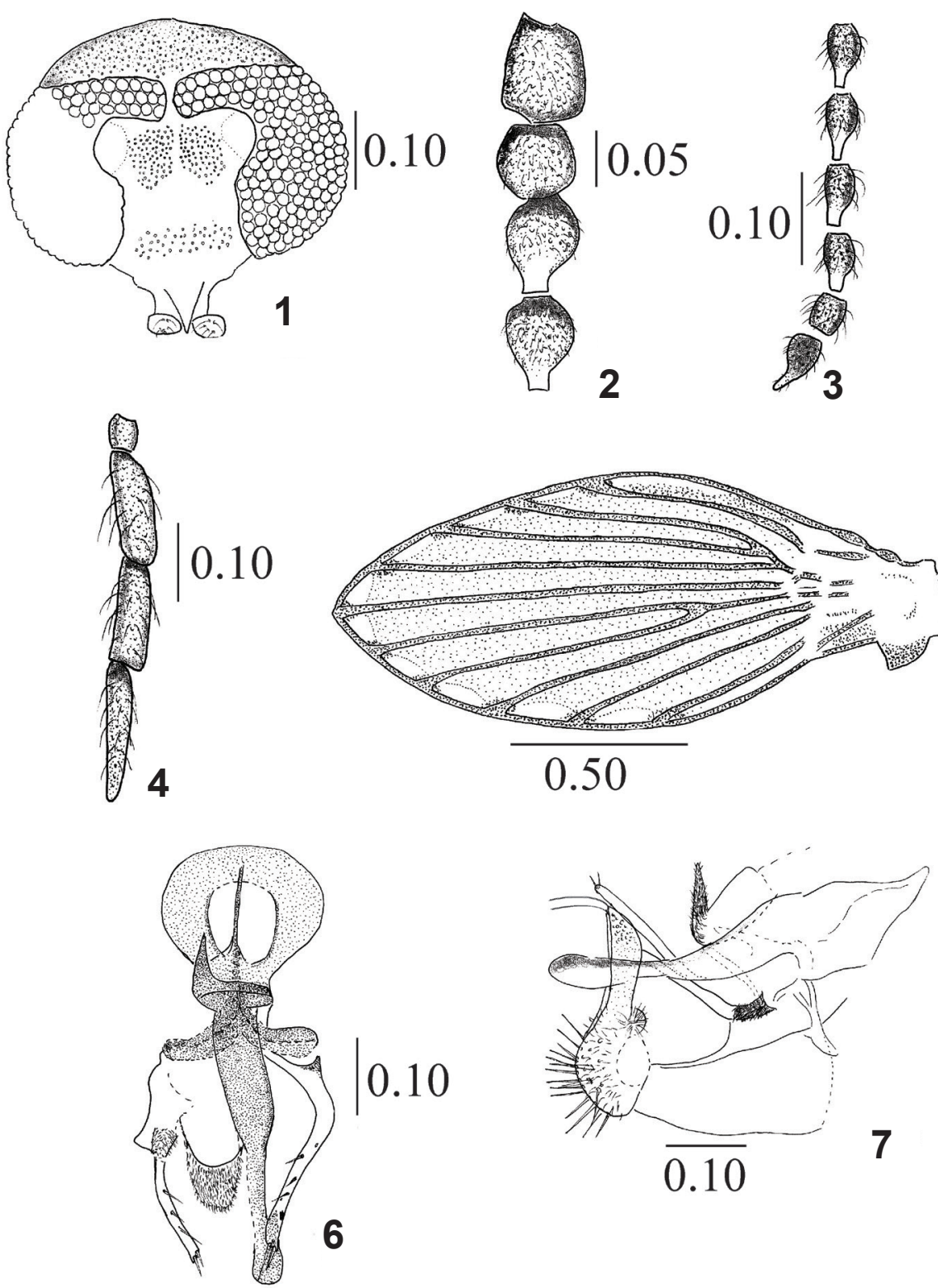

Figs 1-7. Chuspilepia saltenia sp. nov., male. 1, Head, frontal view; 2, scape, pedicel and first and second flagellomere; 3, Flagellomeres 9-14; 4, palpus; 5, wing; 6, genitalia in part showing the gonopods (gonocoxites and gonostyli) and the aedeagal complex; 7 , genitalia in lateral view. Measurements in $\mathrm{mm}$.

external edges with small comb ornamentation (Fig. 12). Hypovalve incospicuos. Cercus shorts, two times longer than subgenital plate (Fig. 12).

Measurements (in $\mathrm{mm}$ ): head high: 0.37 , width: 0.52; mouthparts length (from clypeus inferior border to apex of labellum): 0.12 ; palpus length: 0.55 ; antenna length: 1.25 ; wing length: 2.00 , width: 0.82 ; subgenital plate length (from anterior margin to apex of hypovalve): 0.25; cercus length: 0.29 .

Pupa (Figs 13-18). Color light brown, body ovoid. Tip of wings extending beyond the tip of legs $(0.06 \mathrm{~mm})$ (Fig. 13). Abdomen with eight segments. Chaetotaxy: Head (Fig. 14) with setae c short, same length than setae g. Setae $\mathrm{h}$ very short, in frontal view on the left side, in the place of setae $\mathrm{h}$ two small setae are observed, on the right side only one setae is observed (Fig. 14). Other small setae are also observed in the frontclypeal sclerite, as illustrated in Fig. 14. Abdomen with same pattern of chaetotaxy from segment 2 to 7 , as follow: each lateral side of every sternite with one large setae (setae 15). Anterior margin of every sternite with four short setae (Fig. 13, 16), posterior margin with 9 setae. Exterior lateroanal setae (al) (Fig. 16) short, but two times longer than the interior lateroanal setae (il). Dorsally (Figs 15, 17) the body has small prominent bumps all over its surface, without any setae. This small bumps form a single row at distal portion on every tergite and accumulate in the midline of every segment forming a continuous line in the dorsum of the abdomen (interrupted 

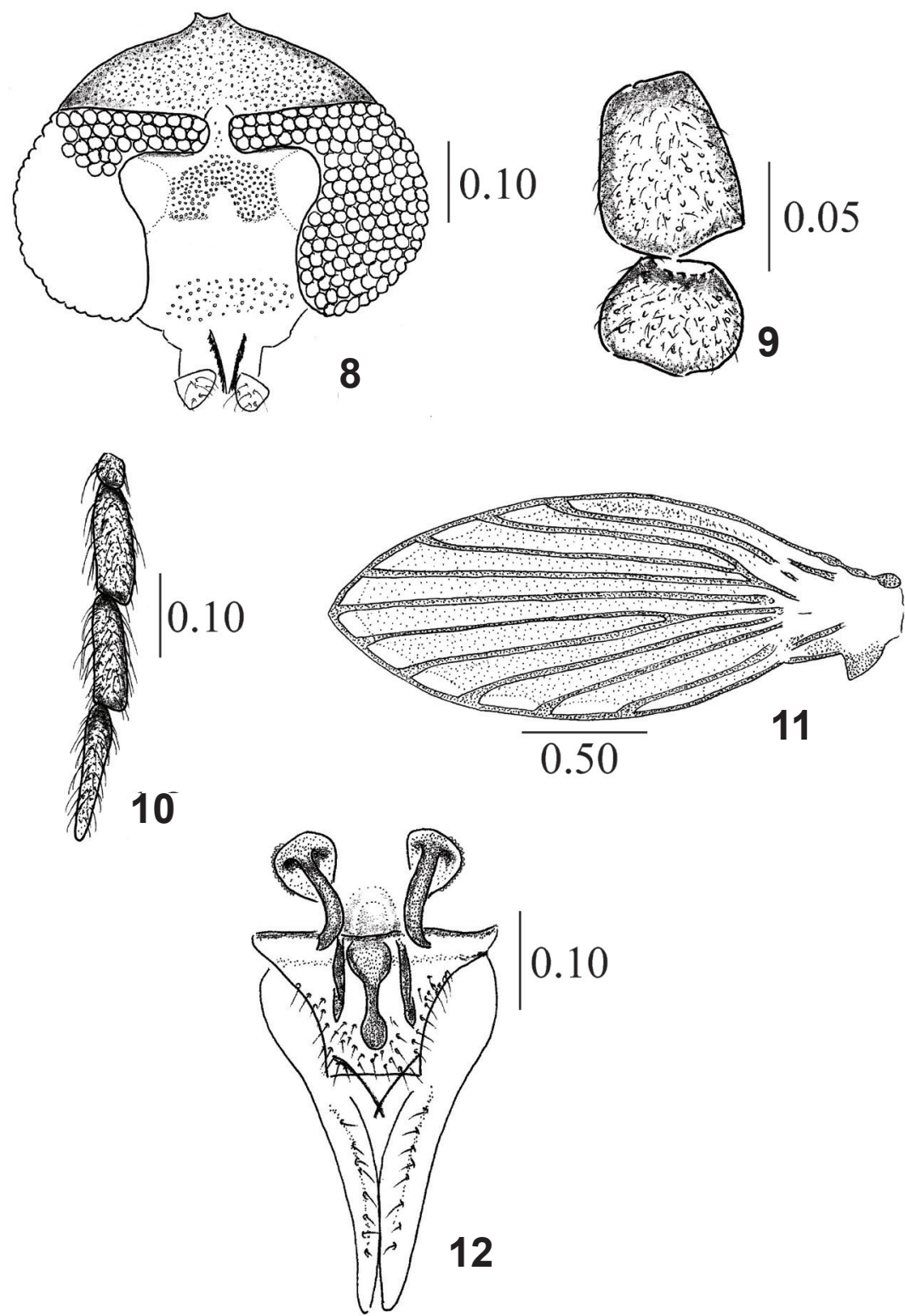

Figs 8-12. Chuspilepia saltenia sp. nov., female. 8, Head, frontal view; 9, scape and pedicel; 10, palpus; 11, wing; 12, postabdomen, ventral view. Measurements in $\mathrm{mm}$.

only by the separation between the segments) on the back of the pupa (Figs 15, 17). Respiratory horn (Fig. 18) nearly conical, four times as long as its central width, with a single row of pits rounded at apex of horn. Measurements (in mm, $\mathrm{n}=4$ ): total length: 3.4-3.9; maximum width: 1.05-1.15; respiratory horn total length: $0.22-0.24$.

\section{DISCUSSION}

Adults of Chuspilepia share some similarities with adults of Alepia and Neurosystasis, such as eye bridge with three facet rows (sometimes four in Alepia), last three flagellomeres not reduced, anterior gonocoxal apodemes expanded and plate like and asymmetrical aedeagal complex. In particular, Chuspilepia also shares with Neurosystasis the fused gonopods, but differs from it by the absence of interocular suture or bifurcated cercus, by having the vein $R_{2+3}$ attached to $R_{4}$ and by the dimorphic gonocoxite. With Alepia, it also shares, the infuscate pattern on the wing membrane, but differs from it mainly in the absence of the accessory tenacula with modified tips presents in the cercus, diagnostic of this genus. Instead, Chuspilepia shows strong spine like setae at the base of the cercus, and the apical tenacula is replaced by two short thin setae.

Chuspilepia has not unique characters that define it, but it has a combination of characters not found in other genera of Psychodinae such as: anterior gonocoxal apodeme expanded (but in the shape of small oval plates); wings membrane infuscated; last three flagellomeres not reduced, flagellomere 13 nearly square, $R_{2+3}$ very short, aedeagal complex strongly asymmetrical and fused gonopods.

Chuspilepia saltenia sp. nov. is characterized by 


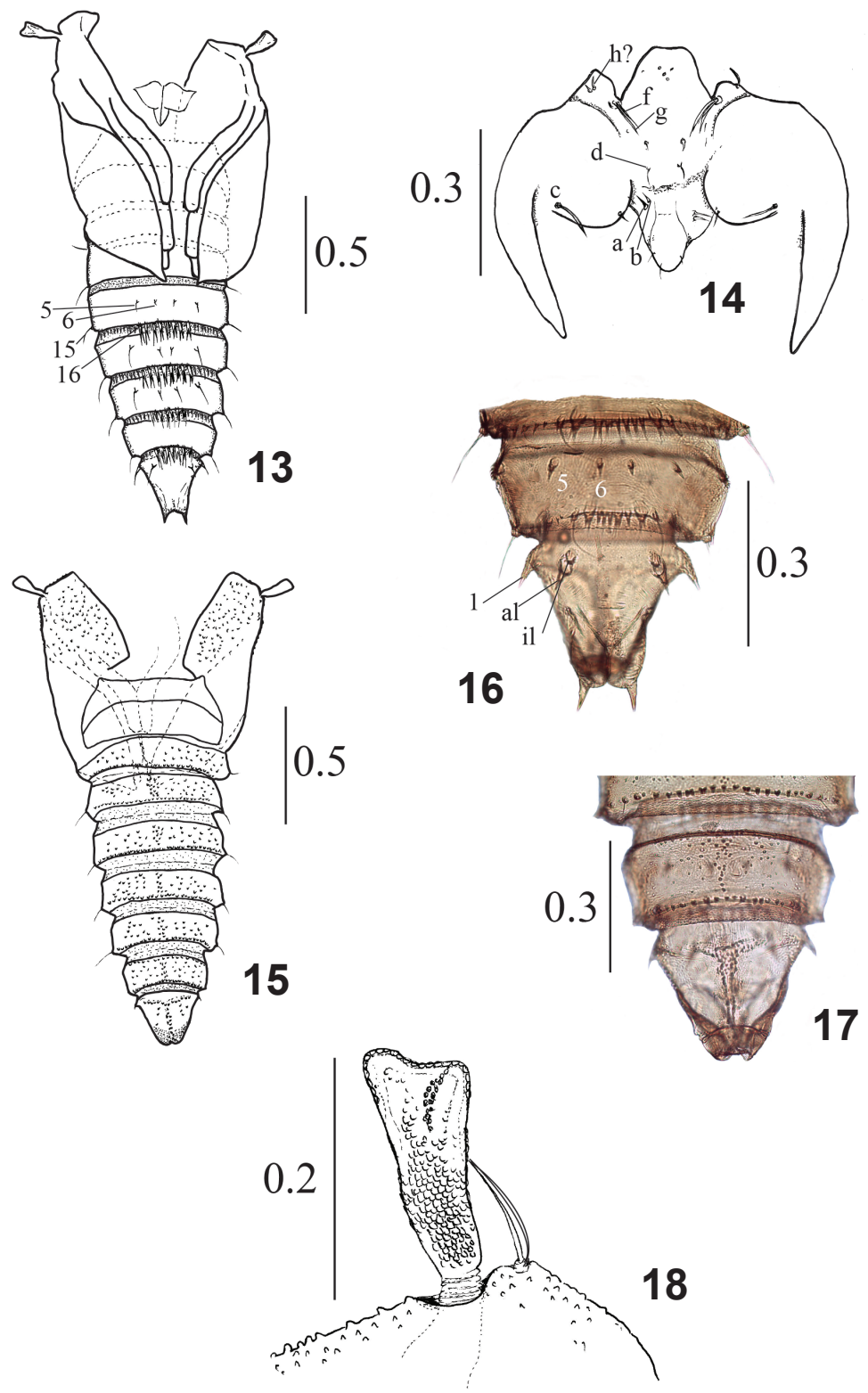

Figs 13-18. Chuspilepia saltenia sp. nov., pupa. 13, ventral view; 14, head sclerites, frontal view; 15, pupa, dorsal view; 16, segment 8 in detail, ventral view; 17, segment 8 in detail, dorsal view; 18, respiratory horn. Measurements in mm.

the asymmetric and thin gonocoxites fused to gonostylus. Also, C. saltenia possess very strong spine like setae at the globular base of cercus and without apical tenacula, instead with two long and thin setae. So far, as it is mentioned in the diagnosis, $C$. saltenia is the only described species of the genus, but the knowledge of the neotropical fauna of Psychodidae of Argentina is extremely poor, and the description of new species is possible.

Immature stages of Psychodidae are poorly known, and there are not many features that stand out in the immature stages of Chuspilepia saltenia sp. nov., however this is usual because most Psychodinae pupae and larvae are very similar. In case of the pupae, they usually possess cylindrical dorso-ventrally flattened body and have protothoracic respiratory organs (QUATE \& VOCKEROTH, 1981). Also characteristic are abdominal segments with one or more transverse rows of spines forming rings, posterior segments modified and somewhat rectangular with two pairs, one dorsal and one ventral, of spines (QUATE \& VOCKEROTH, 1981; IbÁÑEZ-BERNAL, 2000). However, the variety of forms of the respiratory horns is usually used to separate species of Psychodinae (SATCHELL, 1948; OMAD et al., 2013) as well as the chaetotaxy (both larval and pupal stage) (VAILlant, 1971; Bravo et al., 2014). The respiratory horn in C. saltenia sp. nov. resembles that of Clytocerus americanus (Kincaid, 1899) described by CURLER \& MOULTON (2011) since both have a single groove of small pits at apex, however in description of CURLER \& Moulton (2011) no other information is provided and there are no figures accompanying the descriptions.

The pupae of Chuspilepia saltenia sp. nov. were found in tree holes located at up to two meters high in a 
wooded area of the yunga forest, showing once again, and according to other authors (FRANK \& LOUNIBOS, 2009; Bravo et al., 2010, 2014; OMAD et al., 2013) the importance of phytotelmata for Psychodinae breeding. Likewise, immature stages of Alepia and Neurosystasis are also found in Phytotelmata (QUATE \& BROWN, 2004; WAGNER \& HRIBAR, 2004; WAGNER \& SVENSSON, 2006; WAGNER et al., 2008, 2010) which could reinforce the idea that these genera share features and could be related.

Acknowledgements. This paper was partially funded by Consejo Nacional de Investigaciones Científicas y Técnicas CONICET, SECYTUniversidad Nacional de Córdoba and CIUNSA. The senior author wants to thank Dr. Freddy Bravo, for his valuable comments and Dr. Pablo Pessacq for the critical reading of the manuscript. Thanks also to anonymous reviewers for valuable comments that greatly improved the manuscript. G. Omad, and C. Mangudo hold a posdoctoral scholarship from CONICET. R.M. Gleiser is a Career Member of CONICETArgentina.

\section{REFERENCES}

Alexander, B.; Freitas, J. M. \& Quate, L. W. 2001. Some Psychodidae (Diptera) from Atlantic forest in South-Eastern Brazil, with description of Trichomyia dolichopogon sp. nov. and Trichomyia riodocensis sp. nov. Brazilian Journal of Biology 61(3):467-474.

Andrade, A. J. \& Gurgel-Gonçalves, R. 2015. New record and update on the geographical distribution of Pintomyia monticola (Costa Lima, 1932) (Diptera: Psychodidae) in South America. Check List 11(2):1-6.

Bravo, F.; Cordeiro, D. \& Jocque, M. 2014. A new genus of Psychodinae (Diptera, Psychodidae) from Phytotelmata in a Honduran cloud forest. Zootaxa 3841(3):418-428.

Bravo, F.; Silva Lopes, P. \& Bastos, S. 2010. A new Brazilian species of Psychoda Latreille, 1796 (Diptera, Psychodidae) collected in a bromeliad. Biota Neotropica 10:167-169.

Curler, G. R. \& Moulton, J. K. 2011. A review of Nearctic Clytocerus (Diptera: Psychodidae: Psychodinae). The Canadian Entomologist 144:186-195.

FRANK, J. H. \& Lounibos, L. P. 2009. Insects and allies associated with bromeliads: a review. Terrestrial Arthropod Review 1:125-153.

IbÁÑ̃z-Bernal, S. 1994. Maruina (Maruina) pebeta: A new species of Torrenticolous Psychodidae (Diptera) of Cordoba Province, Argentina. Revista Brasileira de Entomologia 38:57-62.

Mangudo, C.; Aparicio, J. P. \& Gleiser, R. M. 2010. Tree holes as larval habitats for Aedes aegypti in public areas in Aguaray, Salta province, Argentina. Journal of Vector Ecology 36:227-230.
McAlpine, J. F. 1981. Morphology and terminology, Adults. In: McAlpine, J. F.; Peterson, B. V.; Shewell, G. E.; Teskey, H. J.; Vockeroth, J. R. \& Wood, D. M. eds. Manual of Neartic Diptera. Vol. 1. Ottawa, Research Branch Agriculture Canada, Monograph 27, p. 9-63.

Müller, G. A. \& Marcondes, C. B. 2006. Bromeliad-associated mosquitoes from Atlantic forest in Santa Catarina Island, southern Brazil (Diptera, Culicidae), with new records for the State of Santa Catarina. Iheringia, Série Zoologia 96:315-319.

OMAD, G. 2012. Inventario preliminar y nuevos registros de Psychodidae no Phlebotominae (Diptera, Nematocera) para Argentina, con especial referencia a la Patagonia. Revista de la Sociedad Entomológica Argentina 71:257-264.

2014. Two new species of Didicrum Enderlein (Diptera, Psychodidae, Psychodinae) from Argentinean Patagonia. Zootaxa 3794(4):565-574.

Omad, G. \& Rossi, G. C. 2012. A new species and records of Alepia Enderlein (Diptera, Psychodidae, Psychodinae) from Argentina. Zootaxa 3397:62-68.

Omad, G.; Mangudo, C.; Anjos-Santos, D. \& Gleiser, R. M. 2013. Descriptions of pupae of three Psychodinae species (Diptera: Psychodidae) from Argentina. Annales Zoologici 63(3):401-408.

Quate, L. W. \& Brown, B. V. 2004. Revision of Neotropical Setomimini (Diptera: Psychodidae: Psychodinae). Contribution in Science 500:1-117.

Quate, L. W. \& Vockeroth, J. R. 1981. Psychodidae. In: McAlpine, J. F.; Peterson, B. V.; Shewell, G. E.; Teskey, H. J.; Vockeroth, J. R. \& Wood, D. M. eds. Manual of Nearctic Diptera. Vol. 1. Ottawa, Research Branch Agriculture Canada, Monograph 27, p. 293-300.

Salomón, O. D. 2008. Psychodidae. In: Claps, L. E.; Debandi, G \& Roig-JuñEnt, S. eds. Biodiversidad de Artrópodos argentinos, Vol. 2. Mendoza, SEA Ediciones, p. 253-270.

SATCHELl, G. H. 1948. The respiratory horns of Psychoda pupae (Diptera: Psychodidae). Parasitology 39:43-52.

Wagner, R. \& Hribar, L. J. 2004. Moth flies (Diptera: Psychodidae) from the Florida Keys with the description of a new Alepia species. Studia Dipterologica 11:505-511.

WaGner, R. \& Ibáñez-Bernal, S. 2009. Psychodidae (sand flies and moth flies or owl flies). In: Brown, B. V.; Borkent, A.; Cumming, J. M.; Wood, D. M.; Woodley, N. E. \& Zumbado, M. A. eds. Manual of Central American Diptera Vol. I. Ottawa, NRC Research Press, p. 319-333.

Wagner, R.; Richardson, B. A. \& Richardson, M. J. 2008. A new psychodid species from Puerto Rican tank bromealids. Studies on Neotropical Fauna \& Environment 43:209-206.

. 2010. A new psychodid species from Saban tank bromeliads. Studies on Neotropical Fauna \& Environment 45:121-127.

WAGNER, R. \& Svensson, B. W. 2006. The exceptional discovery of a new Neotropical moth fly in Sweden (Diptera Psychodidae). Studia Dipterologica 13:99-102. 